\title{
Histopathological, Immunological, Hematological and Biochemical Effects of Fipronil on Nile Tilapia (Oreochromis Niloticus)
}

\author{
Abd elhakeem EI-Murr ${ }^{1}$, Tamer $S$ Imam ${ }^{2}$, Hakim $\mathbf{Y}^{1}$ and Wael AM Ghonimi ${ }^{*}$ \\ ${ }^{1}$ Department of Fish Diseases and Management, Faculty of Vet Medicine, Zagazig University, Egypt \\ ${ }^{2}$ Department of Forensic Medicine \& Toxicology, Faculty of Vet, Medicine, Zagazig University, Egypt \\ ${ }^{3}$ Department of Histology and Cytology, Faculty of Vet Medicine, Zagazig University, Egypt
}

"Corresponding author: Wael AM Ghonimi, Department of Histology and Cytology, Faculty of Vet Medicine, Zagazig University, Egypt, Tel: 00201222498246; Fax: +2-055-2283683; E-mail: drwael_histology@yahoo.com; waghonimi@zu.edu.eg

Rec date: Jun 12, 2015; Acc date: Aug 28, 2015; Pub date: Aug 31, 2015

Copyright: $\odot 2015$ El-Murr AE, et al. This is an open-access article distributed under the terms of the Creative Commons Attribution License, which permits unrestricted use, distribution, and reproduction in any medium, provided the original author and source are credited.

\begin{abstract}
The current experiment was carried out to measure the effects of different concentrations of Fipronil on the immune response and health of Oreochromis niloticus through the evaluation of some immunological, biochemical and hematological parameters in addition to histopathological examination. Two hundred and forty Oreochromis niloticus were randomly distributed into four groups in triplicates. The first group served as a control. The second group exposed to $0.014 \mathrm{mg} /$ which equal to $1 / 396 \mathrm{hr}$ lethal concentration $\left(96 \mathrm{hr} \mathrm{LC}_{50}\right.$ ) for 4 days. The third and fourth groups were exposed to 0.0042 and $0.002 \mathrm{mg} / \mathrm{l}\left(1 / 10\right.$ and $1 / 20$ 96hr $\left.\mathrm{LC}_{50}\right)$ respectively for 10 weeks. The mortality rate in fish exposed to $0.014 \mathrm{mg} / \mathrm{l}$ of fipronil was $53 \%$, meanwhile it was $21 \%$ and $8 \%$ in fish exposed to 0.0042 and $0.002 \mathrm{mg} / \mathrm{l}$ for 10 weeks respectively. Fish exposed to fipronil showed pale gills and nervous manifestations beside congestion and hemorrhages of different internal organs. There was a significant decrease in the level of Immunoglobulin $\mathrm{M}(\mathrm{IgM})$ and lysozyme with concurrent increasing in the serum nitric oxide level compared with the control group. Significant increase in serum level of AST, ALT and Cortisol in all the exposed groups to Fipronil compared to the control group. Liver and gills of fish exposed to Fipronil showed different histopathological alterations.
\end{abstract}

Keywords: Fipronil; Immunological; Hematological; Biochemical; Histopathological; Nile tilapia (Oreochromis niloticus)

\section{Introduction}

Fresh water ecosystems are considered among the most vulnerable systems worldwide and suffer from a harsh loss of biodiversity in recent times [1]. The various threats to freshwater ecosystems include climate alteration, nutrient swings, acidification, habitat loss, exploitation and biological invasions. In addition to chemical contamination that is considered a substantial factor. A key source of chemical stress is established by indiscriminate and common use of pesticides, primarily in the agricultural sector that eventually leads to pollution of the aquatic environment and thus, it becomes hazardous to the aquatic life $[2,3]$. Increased use of pesticides results in the excess inflow of toxic chemicals into the aquatic ecosystem [4].

Contamination of water with large amounts of pesticides leads to fish mortality or starvation by destruction of food organism. Moreover, many toxicants have been shown affecting the growth parameters and reproduction, with evidence of tissue damage [5].

Fipronil is a new broad-spectrum phenylpyrazole insecticide. The International Union of Pure and Applied Chemistry (IUPAC) name for fipronil is ( \pm )-5-amino-1-(2,6-dichloro- $\alpha, \alpha, \alpha$-trifluoro-p-tolyl)-4trifluoro methyl sulfinyl pyrazole-3-carbonitrile (Tomlin, 2006). Moreover, Fipronil is identified by the US. Environmental Protection Agency (US. EPA) and is used as an alternative to organophosphate compounds $[6,7]$.
Recently, Fipronil is gaining a considerable attention as a minute concentration of Fipronil is highly effective against various insects and pests of crops, notably rice insects, trips and termites [8], owing to its lipophilicity and persistency properties. It has also non-agricultural applications, including control of veterinary pests [9]. Fipronil is used to control ants, beetles, cockroaches, fleas, ticks, termites, mole crickets, thrips, rootworms, weevils, and other insects [10,11]. Fipronil is highly toxic for crustaceans, insects and zooplankton as well as bees, termites, rabbits, the fringe-toed lizard and certain groups of gallinaceous birds. It is also highly toxic to many fish. Moreover, its toxicity is varied within different species. Conversely, the substance is relatively innocuous to passerines, wild fowl and earthworms [12]. There is evidence that Fipronil and some of its degrades may bio accumulate particularly in fish [13]. Fipronil is highly toxic to many non-target organisms, such as honeybees, fish, aquatic invertebrates, and upland game birds. Fipronil causes mortalities in fish with low concentrations $96 \mathrm{hr}$. Acute toxicity studies showed that Fipronil is very highly toxic to bluegill sunfish (LC 50=0.083 ppm) and highly toxic to rainbow trout (LC50 $=0.246 \mathrm{ppm})$ [10].

Due to the high consumption of Nile tilapia by humans and considering the insecticides used in agriculture practice, the possible toxic effects of these products in fish tissues for commercial interest have become of a great concern. So the present investigation was carried out to evaluate the harmful effects of acute and chronic exposure to different concentrations of Fipronil on health and immune response of $O$. niloticus through the measurement of some immunological, biochemical and hematological parameters in addition to histopathological examination. 
Citation: El-Murr AE, Imam TS, Hakim Y, Ghonimi WAM (2015) Histopathological, Immunological, Hematological and Biochemical Effects of Fipronil on Nile Tilapia (Oreochromis Niloticus) . J Veterinar Sci Technol 6: 252. doi:10.4172/2157-7579.1000252

Page 2 of 9

\section{Materials and Methods}

\section{Chemicals}

Technical grade fipronil $\left(\mathrm{C}_{12} \mathrm{H}_{4} \mathrm{C}_{12} \mathrm{~F}_{6} \mathrm{~N}_{4} \mathrm{OS}\right) \quad(99.1 \%$ pure $)$ manufactured by Bio Quest International Private Limited, Mumbai, India. A stock solution of fipronil was primed using analytical grade acetone. Required amount of fipronil was drawn from this stock solution for the experimental use.

$96 \mathrm{hr} \mathrm{LC}{ }_{50}$ fipronil for $O$. niloticus is $0.042 \mathrm{mg} / \mathrm{l}$ according to [14].

\section{Fish}

A total number of two hundred and forty of $O$. niloticus with an average body weight $(35 \pm 1.0 \mathrm{~g})$ were employed in the present study. Fish were obtained from private fish farm Abbassah, Sharkia Province. Fish were apparently healthy and free from any skin lesions or external parasites. Fish were kept in glass aquaria, each aquarium $(80 \times 30 \times 40$ $\mathrm{cm}$ ) provided with aerator and thermostatically controlled heater and filled with clean and dechlorinated water. Fish were acclimatized for two weeks to the laboratory environment before the start of the experiments. They were fed on basal diet containing crude protein $30 \%$. The amount of feed (on dry matter basis) given daily to fish was $5 \%$ of body weight and the fish were fed three times daily. During all experimental period, the average water parameters are as follows: temperature $25.5 \pm 2.01 \mathrm{C}, \mathrm{pH} 6.4 \pm 0.2$, dissolved oxygen $5.1 \pm 2.0$ $\mathrm{mg} / \mathrm{L}$, non-ionized ammonia $0.8 \pm 0.01 \mu \mathrm{g} / \mathrm{L}$ and nitrite $0.06 \pm 0.01$ $\mathrm{mg} / \mathrm{L}$.

\section{Experimental protocol}

Fish were divided into four triplicated groups, at a density of 20 fish per aquarium .The first group kept as a control. Second group was exposed to $0.014 \mathrm{mg} / \mathrm{l}\left(1 / 3\right.$ of $\left.96 \mathrm{hr} \mathrm{LC}_{50}\right)$ for 4 days. Third group was exposed to $0.0042 \mathrm{mg} / \mathrm{l}\left(1 / 10\right.$ of $\left.96 \mathrm{hr} \mathrm{LC} \mathrm{LC}_{50}\right)$ for 10 weeks. Fourth group was exposed to $0.002 \mathrm{mg} / \mathrm{l}\left(1 / 20\right.$ of $\left.96 \mathrm{hr} \mathrm{LC} \mathrm{L}_{50}\right)$ for 10 weeks.

The experimental fish were observed daily, the clinical signs, postmortem lesions of the affected fish and the mortality rate were recorded according to [15].

\section{Samples collection}

At the expiration of the experiment, blood samples were collected by Puncturing caudal blood vessels using a medical syringe which was previously rinsed with EDTA solution (as anticoagulant) and shaken gently to prevent hemolysis of blood which is used for hematological analysis . Serum blood were collected without anticoagulant and stored at $-20^{\circ} \mathrm{C}$ till measurement of immunological and biochemical parameters. Then fish were sacrificed by decapitation and specimens from liver and gills from all groups were kept in neutral buffered formalin for histopathological examination.

\section{Humoral immunological studies}

Lysozyme assay: Serum lysozyme was ascertained by the turbidometric assay [16].

Nitric oxide: The serum nitric oxide production activity was assessed as described by [17].

Assay procedure for IgM evaluation: Immunoglobulin M (IgM) was determined using ELISA Kit, Catalog No.CSB-E12045Fh (96 test).CUSABIO BIOTECH CO.,Ltd.

\section{Estimation of some biochemical parameters}

${ }^{* *}$ Serum aspartate amino transferase (AST), serum alanine aminotransferases (ALT) were measured according to [18], cortisol level were quantified according to [19] and serum level of urea and creatinine was determined $[20,21]$.

\section{Estimation of some hematological parameters}

${ }^{* *}$ Erythrocytes (RBCs) and leukocytes (WBCs) counts were carried out according to the method described by [22], hematocrit packed cell volume (PCV) was measured according to [23] while hemoglobin concentration $(\mathrm{Hb})$ was done according to acid hematin method using forstab haemometer as rapid collection using sahlis method. The attained hemoglobin values were adjusted according to equation of [24].

\section{Histopathological examination}

Specimens from the liver, gills, intestine and skin were gathered and fixed in $10 \%$ buffered neutral formalin solution, dehydrated in gradual ethanol (70-100\%), cleared in xylene, and embedded in paraffin. Fivemicron thick paraffin sections were prepared and then routinely stained with Hematoxylin and Eosin (H\&E) dyes [25] and then eventually examined microscopically.

\section{Statistical analysis}

Statistical analysis employing one-way ANOVA Statistical Analysis System [26]. It was performed to obtain the significant difference at $\mathrm{P}<0.05$ on various parameters between tested groups.

\section{Results and Discussion}

\section{Clinical signs and postmortem lesions}

Pesticides are widely studied in the aquatic Ecotoxicology as large amounts are used in agriculture and livestock in the whole world.

Fish exposured to Fipronil in second group (1/3 LC $\mathrm{L}_{50} / 96 \mathrm{hr}$ ) exhibited nervous and sluggish movement with no reaction to tested reflexes. Furthermore, the body was covered with a dense layer of mucous. Moreover, gills appeared pale with excessive mucous secretion. Postmortem examination showed congestion of all internal organs with extended gall bladder. And also, nervous manifestations were observed due to its mode of action which including the disruption of the normal nerve function by targeting the $\gamma$ aminobutyric acid type [27].

Regarding effect on health, the mortality rate of fish exposed to $0.014 \mathrm{mg} / \mathrm{l}$ of fipronil for four days demonstrated $53 \%$ mortality rate. It was $21 \%$ and $8 \%$ in fish exposed to 0.0042 and $0.002 \mathrm{mg} / \mathrm{l}$ for 10 weeks respectively. These results were in agreement with Colliot et al. [28] who mentioned that fipronil caused mortality too many fish species like rainbow trout and to bluegill sunfish with $96 \mathrm{hr} \mathrm{LC} \mathrm{L}_{50}$ of $0.246 \mathrm{mg}$ $\mathrm{L} / 1$ and $0.083 \mathrm{mg} \mathrm{L} / 1$ respectively.

\section{Humoral immunological parameters}

Table 1 revealed that $O$. niloticus exposed to different concentrations of fipronil for different durations showed significant $(\mathrm{P}<0.05)$ increase in the level of nitric oxide with concurrent significant $(\mathrm{P}<0.05)$ lower lysozyme and $\operatorname{IgM}$ activity in serum of all treated groups with fipronil in comparison with control group. These results were completely in concordance with Gupta et al. [29] who 
Citation: El-Murr AE, Imam TS, Hakim Y, Ghonimi WAM (2015) Histopathological, Immunological, Hematological and Biochemical Effects of Fipronil on Nile Tilapia (Oreochromis Niloticus) . J Veterinar Sci Technol 6: 252. doi:10.4172/2157-7579.1000252

Page 3 of 9

proved the negative effect of fipronil on immune response of fish through decreased serum level of lysozyme and nitroblue tetrazolium(NBT) in Cyprinus carpio fry after exposure to sub lethal dose $\left(1 / 10^{\text {th }} \mathrm{LC}_{50}\right.$ for $\left.96 \mathrm{hr}\right)$ of fipronil for 45 days . Also similar results were obtained by Clasen et al. [30] who found that exposure of cyprinus carpio to $0.65 \mathrm{mg} / \mathrm{l}$ fipronil for 7,30 and 90 days cause changes in the antioxidant profile and elevation of oxidative stress parameters and subsequently altered immune status in different tissues of common carp. The harmful effect on immune response can be explained by exposure to fipronil leading to alterations in superoxide dismutase (SOD) and catalase (CAT) activities. SOD is the first enzyme to respond against free radicals and is the one that offers the greatest response to oxidative stress [31].

\section{Biochemical parameters}

Alanine aminotransferase (ALT) and aspartate aminotransferase (AST) are liver specific enzymes and they are more sensitive measures of hepatotoxicity and histophathalogic changes [32]. Morowati clarified that, the elevation of ALT activity appears to reflect an acute hepatic disease more specifically than using AST values [33].
Exposure of $O$. niloticus to fipronil resulted in significant increase in serum level of ALT and AST (Table 2). Like many toxic chemicals, fipronil has been well known to affect metabolic enzyme profile and thus can alter the physiological and biochemical responses of aquatic organisms [10].

\begin{tabular}{|l|l|l|l|}
\hline \multirow{2}{*}{ Groups } & \multicolumn{2}{l|}{ Parameters } \\
\cline { 2 - 4 } & $\begin{array}{l}\text { Nitric oxide } \\
\boldsymbol{\mu g} / \mathbf{m l}\end{array}$ & $\begin{array}{l}\text { Lysozyme } \\
\boldsymbol{\mu g} / \mathbf{m l}\end{array}$ & Ig M (g/L) \\
\hline Control & $4.22^{\mathrm{a}} \pm 0.06$ & $319.00^{\mathrm{a}} \pm 1.00$ & $0.60 \pm 0.33^{\mathrm{a}}$ \\
\hline Acute $1 / 396 \mathrm{hr} \mathrm{LC}$ & $4.31^{\mathrm{b}} \pm 0.04$ & $280.60^{\mathrm{b}} \pm 1.02$ & $0.19 \pm 0.07^{\mathrm{d}}$ \\
\hline Chronic $1 / 1096 \mathrm{hr} \mathrm{LC}$ & $4.22^{\mathrm{b}} \pm 0.06$ & $260.40^{\mathrm{b}} \pm 1.72$ & $0.31 \pm 0.01^{\mathrm{b}}$ \\
\hline Chronic $1 / 2096 \mathrm{hr} \mathrm{LC} 50$ & $5.33^{\mathrm{c}} \pm 0.08$ & $300.00^{\mathrm{ab}} \pm 2.62$ & $0.23 \pm 0.18^{\mathrm{c}}$ \\
\hline
\end{tabular}

Table 1: Effect of fipronil on nitric oxide, lyzosyme and IgM level in O.niloticus. Means within the same column bearing different superscripts are significant at $\mathrm{p} \leq 0.01$. IgM: immunoglobulin $\mathrm{M}$.

\begin{tabular}{|c|c|c|c|c|}
\hline $\begin{array}{l}\text { Group } \\
\text { (Dose) } \\
\text { Parameters }\end{array}$ & 1 Control & $\begin{array}{l}2 \text { Acute } \\
1 / 396 \mathrm{hr} \mathrm{LC} 50\end{array}$ & $\begin{array}{l}3 \text { Chronic } \\
1 / 1096 \text { hr LC } 50\end{array}$ & $\begin{array}{l}4 \text { Chronic } \\
1 / 2096 \text { hr LC } 50\end{array}$ \\
\hline Creatinine (mg/DL) & $0.22 \pm 0.12^{c}$ & $0.45 \pm 0.14^{a}$ & $0.39 \pm 0.02^{b}$ & $0.38 \pm 0.15^{a b}$ \\
\hline Urea (mg/dl) & $12.10 \pm 0.11^{\mathrm{b}}$ & $22 \pm 0.15^{c}$ & $19 \pm 0.011^{d}$ & $17 \pm 0.02^{\mathrm{ab}}$ \\
\hline $\operatorname{ALT}(\mu / \mathrm{ml})$ & $12 \pm 0.57^{d}$ & $19 \pm 0.57^{a}$ & $17 \pm 0.57^{b}$ & $15 \pm 0.57^{c}$ \\
\hline AST $(\mu / m l)$ & $17 \pm 0.21^{d}$ & $44 \pm 0.23^{a}$ & $34 \pm 0.06^{b}$ & $29 \pm 0.24^{c}$ \\
\hline Cortisol ( $\mu \mathrm{g} / \mathrm{DL})$ & $0.80 \pm 0.16^{b}$ & $2 \pm 0.12^{a}$ & $1.5 \pm 0.03^{a b}$ & $1.4 \pm 0.07^{a b}$ \\
\hline
\end{tabular}

Table 2: The effect on serum level of some biochemical parameters of O.niloticus exposed to different concentrations of fipronil for various durations comparing with control group (Mean $\pm \mathrm{SE}$ ). Means within the same row bearing different superscripts are significant at $\mathrm{p} \leq 0.05$. AST $=$ aspartate aminotransferase. IgM=Immunoglobulin M.

\begin{tabular}{|c|c|c|c|c|}
\hline \multirow{2}{*}{ Groups } & \multicolumn{4}{|l|}{ Parameters } \\
\hline & $\operatorname{Rbcs}\left(10^{6} / \mu \mathrm{L}\right)$ & Pcv (\%) & $\mathrm{Hg}(\mathrm{g} / \mathrm{dL})$ & $\operatorname{TLC}\left(10^{3} / \mu \mathrm{L}\right)$ \\
\hline Control & $1.30^{\mathrm{a}} \pm 0.003$ & $21.0^{\mathrm{a}} \pm 0.30$ & $4.76^{a} \pm 0.08$ & $36.98^{\mathrm{a}} \pm 0.07$ \\
\hline Acute $1 / 396 \mathrm{hr} \mathrm{LC}_{50}$ & $0.36^{b} \pm 0.02$ & $19.2 a^{b} \pm 0.50$ & $4.90^{\mathrm{a}} \pm 0.10$ & $29.35^{b} \pm 1.50$ \\
\hline Chronic $1 / 1096$ hrs LC $_{50}$ & $0.38^{b} \pm 0.02$ & $17.8^{\mathrm{b}} \pm 0.30$ & $4.30^{b} \pm 0.13$ & $27.57^{\mathrm{b}} \pm 1.50$ \\
\hline Chronic $1 / 2096 \mathrm{hr} \mathrm{LC} 50$ & $0.30^{c} \pm 0.01$ & $14.8^{\mathrm{c}} \pm 1.15$ & $4.24^{b} \pm 0.04$ & $30.96^{b} \pm 1.00$ \\
\hline$F$ test & ** & ** & ** & ** \\
\hline
\end{tabular}

Table 3: The effect on some hematological parameters of O.niloticus exposed to different concentrations of fipronil for various durations comparing with control group (Mean \pm SE). Means within the same row bearing different superscripts are significant at $p \leq 0.01$. RBCs=red blood corpuscles, $\mathrm{PCV}=$ Packed cell volume, $\mathrm{Hb}=$ Hemoglobin, TLC=Total Leucocytes counts.

De Aguiar et al. [34] attributed the increase observed in the liver AST to mitochondrial membrane damage. While Arshad et al. [35] revealed that, the raised level in liver AST may be due to enzyme induction as a result of insecticide stress or due to the adverse effect of the insecticide on the oxidation by Kreb's cycle. Thus, the significant increases in liver AST and ALT recorded in the present study could be due to the stress effect of fipronil as an insecticide and due to its hepatotoxic effect.
There was increase in the serum level of kidney function markers (urea and creatinine) and serum cortisol level (Table 2). Gupta et al. [36] observed an elevation in serum level of cortisol of cyprinus carpio fry after exposure to $0.0428 \mathrm{mg} / \mathrm{l}$ fipronil equivalent to (1/10th LC50 for $96 \mathrm{hr}$ ) for 45 days. The elevated level of urea and creatinine may be attributed to alteration of detoxifying power of kidney caused by Fipronil. 


\section{Hematological evaluation}

There was significant $(\mathrm{P}<0.05)$ decrease in erythrocyte count in fipronil treated groups compared with control (Table 3). Previously, Ghisi et al. [37] was not surprised that the lowest recorded concentration of Fipronil $0.0002 \mathrm{mg} / \mathrm{L}(0.2 \mu \mathrm{g} / \mathrm{L})$ causes erythrocyte injury in silver catfish, Rhamdia quelen due to detrimental effect of Fipronil on erythrocytes synthesis.

Hemoglobin content and total leukocytic count in Fipronil exposed fish showed significant $(\mathrm{P}<0.05)$ decreases compared with the control group. This might be due to the fast oxidation of hemoglobin to methemaglobin or release of oxygen radical due to the toxic effect and oxidative stress induced by Fipronil as observed by Clasen et al. [30]. These results were compatible with that obtained by Gupta et al. [36] who found that exposure of caprinus carpio fry to sub lethal dose $\left(1 / 10^{\text {th }} \mathrm{LC}_{50}\right)$ of Fipronil for 45 days resulted in significant decrease in erythocytic count, total leucocytic count (TLC) and $\mathrm{Hb} \%$, however these results were differed from those reported by Gupta et al. [29] and Gill \& Dumka [38]. The latter mentioned that neither hemoglobin concentration nor total erthrocytic count was affected when buffalo calves were exposed to Fipronil at dose level $(0.5 \mathrm{mg} / \mathrm{kg}$ body weight per day). This disagreement most probably will be due to the different species.

\section{Histopathological examination}

Regarding histopathological results, the liver of the control group exhibited a normal hepatocytes and sinusoidal architecture and there were no pathological abnormalities. Liver demonstrated the spongelike appearance of the parenchyma which is primarily composed of large irregular polygonal hepatocytes with typically large single central or subcentral spherical nucleus with prominent nucleoli, and sometimes binucleated. Nucleus is associated with a pale or vacuolar area as a lot of glycogen. Hepatocytes cytoplasm is homogenous. Moreover, hepatocytes were arranged as tubules or cords that are not always clearly visible. Furthermore, cords of hepatocytes were separated by sinusoids that were filled with erythrocytes (Figure 1A).

In group subjected to $0.014 \mathrm{mg} / \mathrm{l}$ of fipronil for 4 days; liver showed focal areas of necroses infiltrated with numerous lymphocytes and few erythrocytes (Figure 1B). Severe congestion in the hepatic blood vessels and sinusoids and hemorrhages among the hepatic cells were seen. Diffuse hydropic degenerations and vacuolations in the hepatocytes were identified. The portal areas showed necrosis the pancreatic acini and lymphocytes infiltrations (Figure 1C). While the liver of the third group that exposed to $(0.0042 \mathrm{mg} / \mathrm{l}$ for 10 weeks; showed severe congestion of the hepatic blood vessels, hemorrhages and diffuse fatty change (Figure 1D). Periportal coagulative necrosis was visualized besides extensive necrosis in the adjacent pancreatic acini. Few eosinophilic hyalinized globules (Mallory bodies) were seen in the cytoplasm of some vacuolated hepatocytes (Figure 1E). The liver of treated group with $0.02 \mathrm{mg} / \mathrm{l}$ for 10 weeks.; showed mild to moderate fatty change, hydropic degeneration and individual hepatocyte necrosis, few hypertrophied hepatocytes were noticed among the degenerated hepatic cells (Figure 1F). Severe congestion and hemorrhages were seen alongside few round cells infiltrations were detected in the portal areas and interstitial tissue (Figure 1G). These results matched with that obtained by Melo [39] who recorded increased foci of necrosis in the liver of silver catfish after 48 and $72 \mathrm{hr}$ of exposure to fipronil. After $96 \mathrm{hr}$ of exposure, the author describes cells indistinguishable contour, presence necrosis focus, in addition of damaged blood vessels, vacuolization of the cytosol and the presence of an unknown material strongly eosin stained in the cytoplasm of the hepatocytes. Blood leukocyte infiltration and congestion were detected in addition to melanomacrophage were found in various locations between the hepatocytes as well as pyknotic nuclei cells. Gills of intoxicated groups with fipronil showing various histopathological changes.

The gills of the control group showed no any significant microscopical abnormalities. The gills were observed made up of double rows of filaments from which arise perpendicularly the lamellae. The lamellae were lined by a squamous epithelium. Below that epithelium were lamellar blood sinuses. Between the lamellae, the filament is lined by a thick stratified epithelium (Figure 2A). Gills of fish subjected to $0.014 \mathrm{mg} / \mathrm{l}$ of fipronil for 4 days; showed focal necrosis and sloughing in the covering epithelium of the secondary lamellae with intense lymphocytes infiltrations (Figure 2B). In some cases, focal epithelial proliferations and fusion were seen at the base of gill filaments besides severe congestion of the lamellar blood capillaries, edema and leukocytic infiltration (Figure 2C). Scarce lymphocytes together with a significant number of EGC were detected at the base of gill filaments. Mucinous degeneration in the lining epithelium of the gill rackers was observed besides edema, extravasated erythrocytes and EGCs infiltration in the submucosa (Figure 2D). The gills of third group that exposed to $0.0042 \mathrm{mg} / \mathrm{l}(1 / 10$ of $96 \mathrm{hr}$ LC50) of fipronil for 10 weeks; revealed extensive hyperplasia of the covering epithelium in the interlamellar spaces, followed by fusion of the lamellae and clubbing of such filaments (Figure 2E). Sometimes, the gill filaments were focally necrotic and infiltrated with lymphocytes. Congestion of ellipsoids and capillaries was observed as well as focal hemorrhages (Figure $2 \mathrm{~F}$ ). The gills of exposed group to $0.002 \mathrm{mg} / \mathrm{l}\left(1 / 20 \mathrm{of} 96 \mathrm{hr} \mathrm{LC} \mathrm{L}_{50}\right)$ for 10 weeks; showed mild hyperplasia in the epithelium of the secondary lamellae and congestion (Figure 2G). Comparable results were declared by Ghisi [37] who researched the effects of the phenyl pyrazole fipronil in the gills of the silver catfish after 60 days of intoxication in the sublethal concentrations $0.05 ; 0.10$ and $0.23 \mu \mathrm{g} / \mathrm{L}$. The latter described hyperplasia, lamellar fusion and aneurysms in all treated groups that can impair the gill function. However, we consider the injuries of low severity and possible regression if the source of stress is eliminated, since the concentration of fipronil used was very low. Lamellar fusion is a nature of defense mechanism to protect the epithelium of the lamella from direct contact with toxic agents [40].

Intestine of the control group exhibited a normal tunica mucosa, submucosa, muscularis and serosa and there were no pathological abnormalities (Figures 3A and 3B). The intestinal mucosa is the inner most layers and has a deep finger-like processes; villi that extending in the organ lumen (Figures $3 \mathrm{~A}$ and $3 \mathrm{~B}$ ). These expansions are lined by a simple columnar epithelium comprising mainly absorptive cells and mucus-secreting or goblet cells (Figure 3C).

The lamina propria and submucosa are generally composed of a loose connective tissue containing blood and lymph capillaries and large numbers of wandering eosinophilic granular cells and variable quantities of lymphoid tissue. The role of the eosinophilic granular cells (EGCs) comes as containing antimicrobial peptides and their degranulation that can increase the vascular permeability and promote neutrophil adhesion, suggesting that they are intimately involved in innate immunity and inflammation (Figures 3C and 3D). The muscularis mucosa usually consists of a thin layer of smooth muscle cells, longitudinal in direction. The intestine is covered externally with tunica serosa that is mainly formed of vascularized loose connective tissue; tunica adventitia and mesothelium of simple squamous epithelium (Figure 3 D). 
Citation: El-Murr AE, Imam TS, Hakim Y, Ghonimi WAM (2015) Histopathological, Immunological, Hematological and Biochemical Effects of Fipronil on Nile Tilapia (Oreochromis Niloticus) . J Veterinar Sci Technol 6: 252. doi:10.4172/2157-7579.1000252
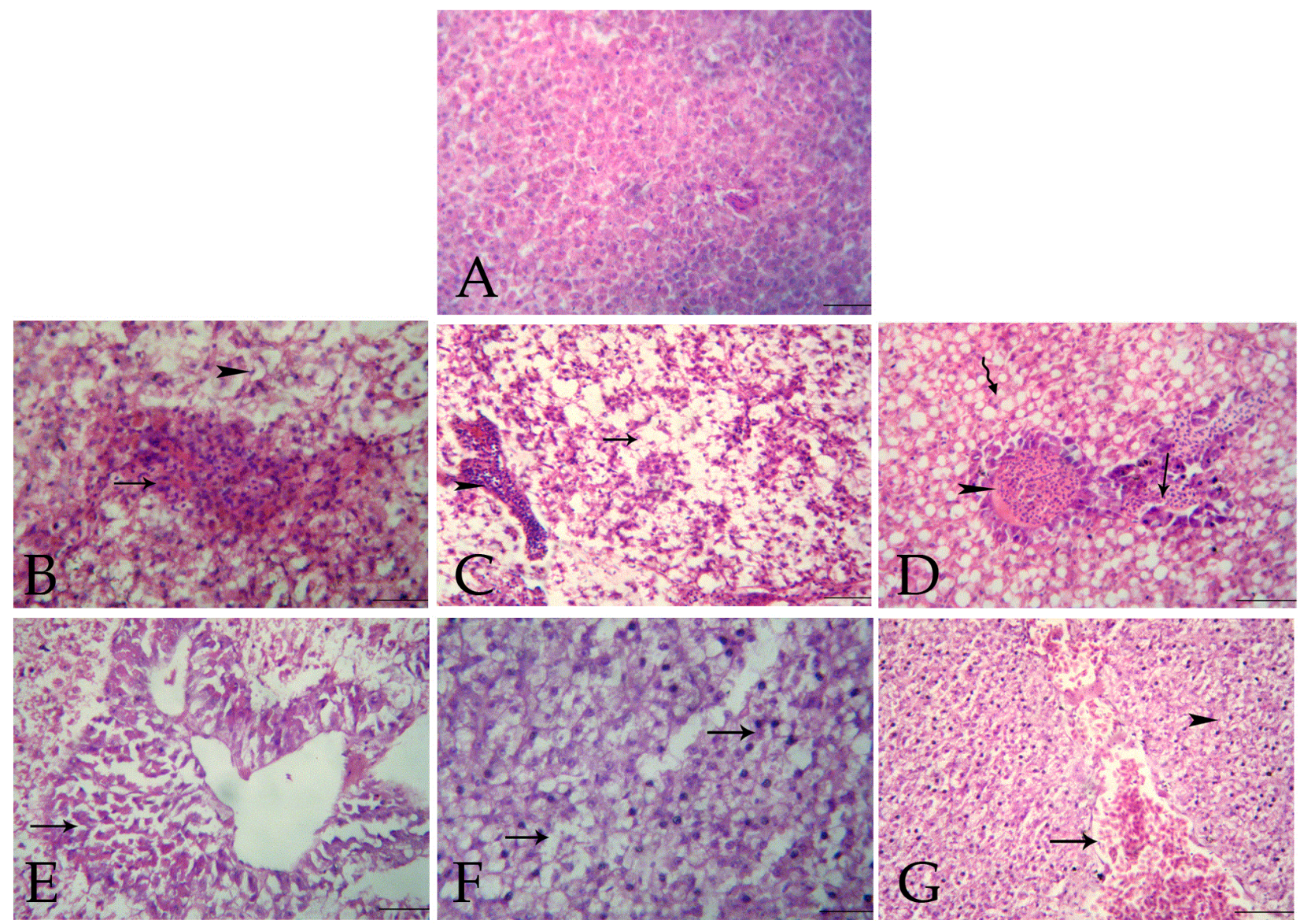

Figure 1A: Section of O.niloticus liver showing normal hepatocyte and sinusoidal architectures, H\&E (Bar=100 $\mu \mathrm{m})$. Figure 1B: Section of O.niloticus liver of second group showing focal area of necrosis infiltrated with numerous lymphocytes and few erythrocytes (arrow) and severe hydropic degeneration (arrowhead), H\&E (Bar=100 $\mu \mathrm{m}$ ). Figure 1C: Section of O.niloticus liver of second group showing diffuse hydropic degenerations and vacuolations in the hepatocytes (arrow), and lymphocytes infiltrations in the portal area (arrowhead), H\&E $($ Bar $=100 \mu \mathrm{m})$. Figure 1D: Section of O.niloticus liver of third group showing severe congestion of the hepatic blood vessels (arrowhead), hemorrhages (arrow) and diffuse fatty change (irregular arrow), H\&E (Bar=100 $\mu \mathrm{m})$. Figure 1E: Section of O.niloticus liver of third group showing coagulative necrosis in the pancreatic acini (arrow), H\&E (Bar=100 $\mu \mathrm{m})$. Figure 1F: Section of O.niloticus liver of fourth group showing moderate fatty change and hydropic degeneration (arrows), H\&E (Bar=100 $\mu \mathrm{m}$ ). Figure 1G: Section of O.niloticus liver of fourth group showing severe congestion and hemorrhages (arrow) besides hydropic degeneration (arrowhead), H\&E (Bar=100 $\mu \mathrm{m})$.

Intestine of fish subjected to $0.014 \mathrm{mg} / \mathrm{l}$ of fipronil for 4 days; showed severe necrosis in the intestinal villi. The necrotic areas were infiltrated with lymphocytes and macrophages (Figure 3E). The intestinal lumina showed desquamated epithelium, leukocytes and erythrocytes. The remaining epithelia revealed mucinous degeneration. The small intestine of the third group that exposed to $0.0042 \mathrm{mg} / \mathrm{l}$
(1/10 of $\left.96 \mathrm{hr} \mathrm{LC}_{50}\right)$ of fipronil for 10 weeks; revealed intact mucosa with moderate mucinous degeneration and few lymphocytes in the submucosa (Figure 3F). The intestine of exposed group to $0.002 \mathrm{mg} / \mathrm{l}$ $\left(1 / 20\right.$ of $\left.96 \mathrm{hr} \mathrm{LC} \mathrm{L}_{50}\right)$ for 10 weeks; revealed mucinous degeneration and desquamation of the lining epithelium. Mild edema and few lymphocytes infiltrations were recorded in the submucosa (Figure 3G). 
Citation: El-Murr AE, Imam TS, Hakim Y, Ghonimi WAM (2015) Histopathological, Immunological, Hematological and Biochemical Effects of Fipronil on Nile Tilapia (Oreochromis Niloticus) . J Veterinar Sci Technol 6: 252. doi:10.4172/2157-7579.1000252
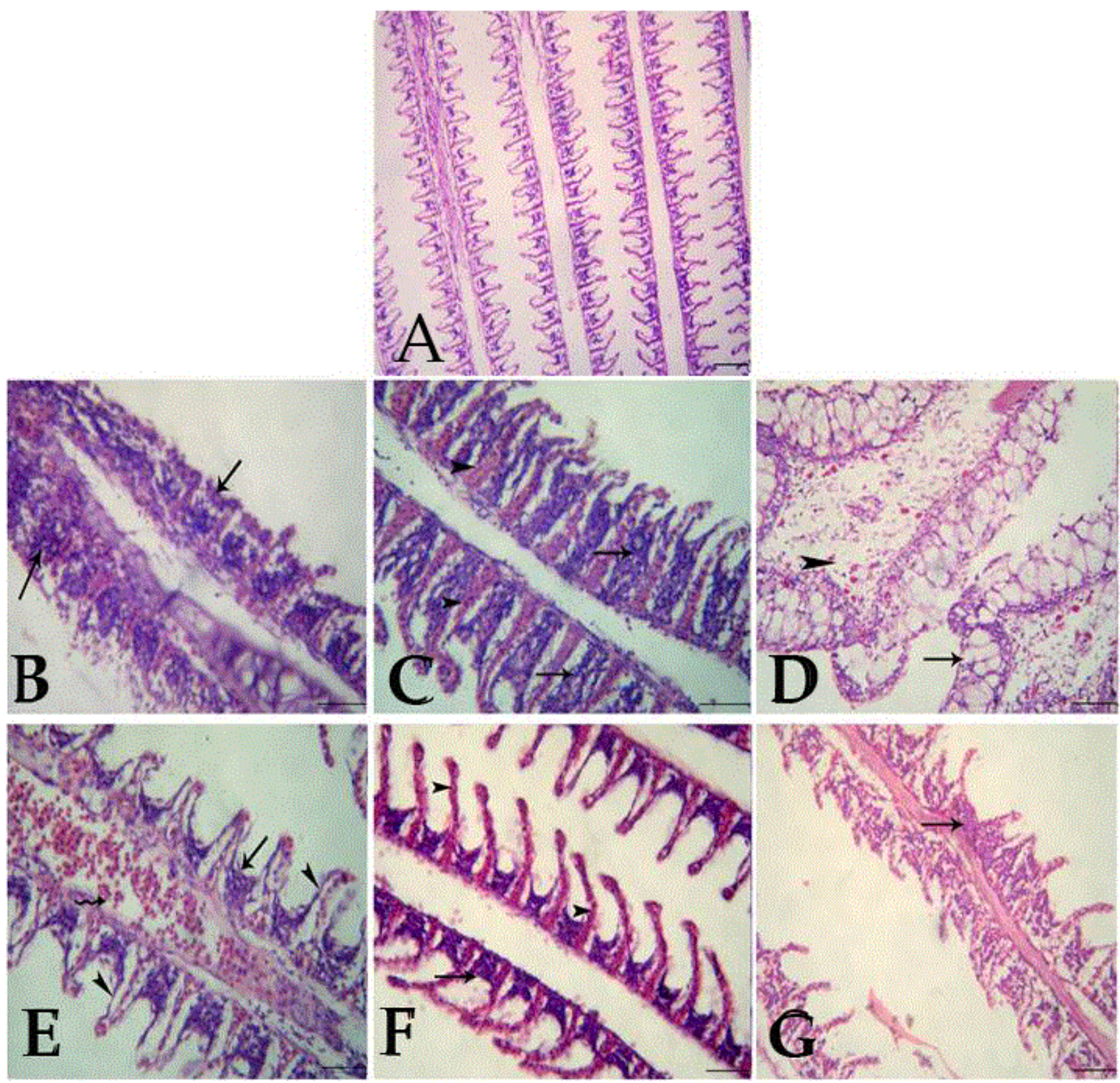

Figure 2A: Section of O.niloticus gills of control group showing normal filaments and lining epithelium, H\&E (Bar=100 $\mu \mathrm{m})$. Figure 2B Section of O.niloticus gills of second group showing focal necrosis and sloughing in the covering epithelium of the secondary lamellae with intense lymphocytes infiltrations (arrows), H\&E (Bar=100 $\mu \mathrm{m}$ ). Figure 2C: Section of O.niloticus gills of second group showing epithelial proliferations and fused at the base of gill filaments (arrows) besides severe congestion of the lamellar blood capillaries (arrowheads), H\&E $(B a r=100 \mu \mathrm{m})$. Figure 2D: Section of O.niloticus gills racker of second group showing mucinous degeneration in the lining epithelium (arrow) and edema and EGCs infiltration in the submucosa (arrowhead), H\&E (Bar=100 $\mu \mathrm{m})$. Figure 2E: Section of O.niloticus gills of third group showing hyperplasia of the covering epithelium in the interlamellar spaces, followed by fusion of the lamellae (arrow), congestion (arrowheads) and hemorrhages (irregular arrow), H\&E (Bar=100 $\mu \mathrm{m})$. Figure 2F: Section of O.niloticus gills of third group showing severe congestion and focal hemorrhages (arrowhead) besides the hyperplasia in the lining epithelium (arrow), H\&E (Bar=100 $\mu \mathrm{m}$ ). Figure 2G: Section of O.niloticus gills of fourth group showing mild hyperplasia in the epithelium of the secondary lamellae and congestion (arrow), H\&E $(\mathrm{Bar}=100 \mu \mathrm{m})$. 
Citation: El-Murr AE, Imam TS, Hakim Y, Ghonimi WAM (2015) Histopathological, Immunological, Hematological and Biochemical Effects of Fipronil on Nile Tilapia (Oreochromis Niloticus) . J Veterinar Sci Technol 6: 252. doi:10.4172/2157-7579.1000252
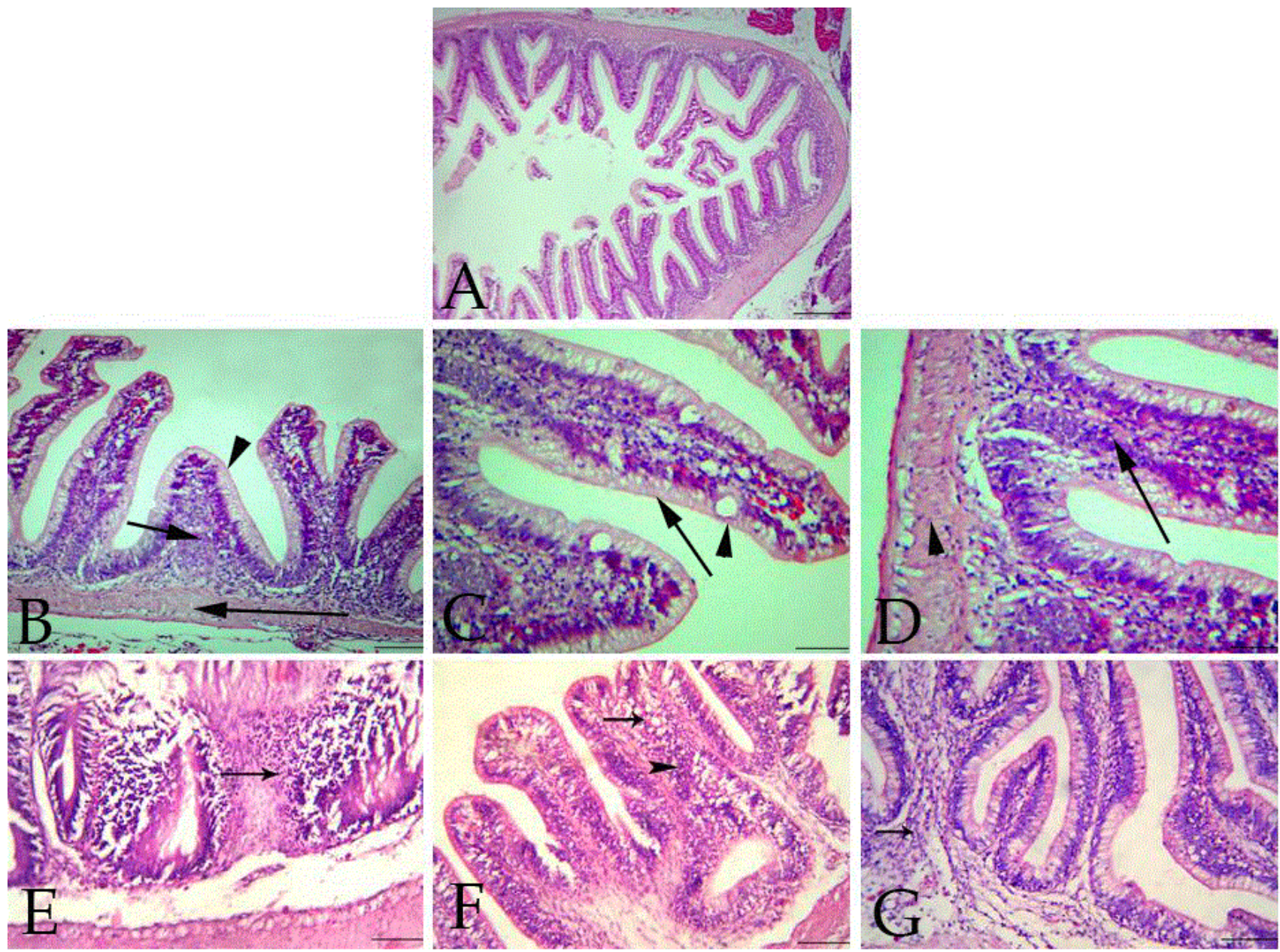

Figure 3A: Section of O.niloticus intestine of control group showing normal mucosa, submucosa and muscularis, H\&E (Bar=100 $\mu \mathrm{m})$. Figure 3B: Section of O.niloticus intestine of control group showing normal mucosa (arrow head), normal submucosa (short arrow) and normal

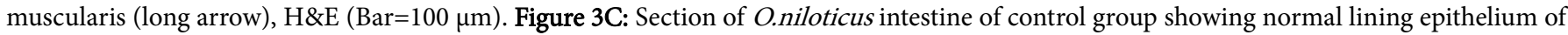
simple columnar cells (arrow) with scattered goblet cells (arrow head), H\&E (Bar=100 $\mu \mathrm{m}$ ). Figure 3D: Section of O.niloticus intestine of control group showing normal submucosa (arrow) and normal muscularis (arrow head), HE (Bar=100 $\mu \mathrm{m})$. Figure 3E: Section of O.niloticus intestine of second group showing severe necrosis in the intestinal villi and lymphocytes and macrophages infiltrations $($ arrow), $\mathrm{H} \& \mathrm{E}(\mathrm{Ba}=100$ $\mu \mathrm{m}$ ). Figure 3F: Section of O.niloticus intestine of third group showing intact mucosa with moderate mucinous degeneration (arrow) and few lymphocytes in the submucosa (arrowhead), H\&E (Bar=100 $\mu \mathrm{m})$. Figure 3G: Section of O.niloticus intestine of fourth group showing mild edema and few lymphocytes infiltrations in the submucosa (arrow), H\&E (Bar=100 $\mu \mathrm{m})$.

Skin of the control group exhibited a normal epidermis, dermis and dermal skeletal muscles and there were no pathological abnormalities (Figure 4A). The epidermis is the outer most layer of the skin and is consisting of a non-keratinizing stratified squamous epithelium that varies in thickness from 3-5 cells. Dermis usually is made up of two strata: an upper spongiosum (laxum) of collagen and reticular fibers, nerves, capillaries, fibroblasts and pigment cells and situated beneath the epidermis and a deeper compactum. The latter, is more developed than the stratum laxum and is formed by densely compressed bundles of collagen fibers that run parallel to the skin surface. Beneath the dermal layer is two bundles of striated muscle; outer circular and inner longitudinal (Figure 4A). Skin of fish subjected to $0.014 \mathrm{mg} / \mathrm{l}$ of fipronil for 4 days; showed intact epidermis with severe proliferation of epidermal cells, spongiosis and hydropic degeneration (Figure 4B). The underlying dermis and hypodermis revealed Zenker's necrosis and inflammation. The latter was represented by numerous round cells infiltrations and few extravasated erythrocytes (Figure 4C). Edema and numerous melanin-carrying were rarely separated the epidermis from the dermis. Sometimes, the epidermis was focally eroded. Skin of the third group that exposed to $0.0042 \mathrm{mg} / \mathrm{l}\left(1 / 10 \mathrm{of} 96 \mathrm{hr} \mathrm{LC} \mathrm{L}_{50}\right)$ of fipronil for 10 weeks; revealed increased of mucous cells and slight vacuolations of the epidermal cells. The dermis particularly at the subepithelial zone showed congested capillaries, edema and aggregations of the leukocytes and melanin-carrying cells (Figure 4D). Sometimes, erosions in the epidermis were noticed with destructed or desquamated epithelium. The underlying muscles showed edema, hyaline degeneration and infiltrated with few lymphocytes (Figure $4 \mathrm{E})$.The skin of exposed group to $0.002 \mathrm{mg} / \mathrm{l}\left(1 / 20\right.$ of $\left.96 \mathrm{hrs} \mathrm{LC}_{50}\right)$ for 10 weeks showed intact epidermis with activation of melanomacrophages in the dermis (Figure 4F). Edema and inflammation were rarely detected. 

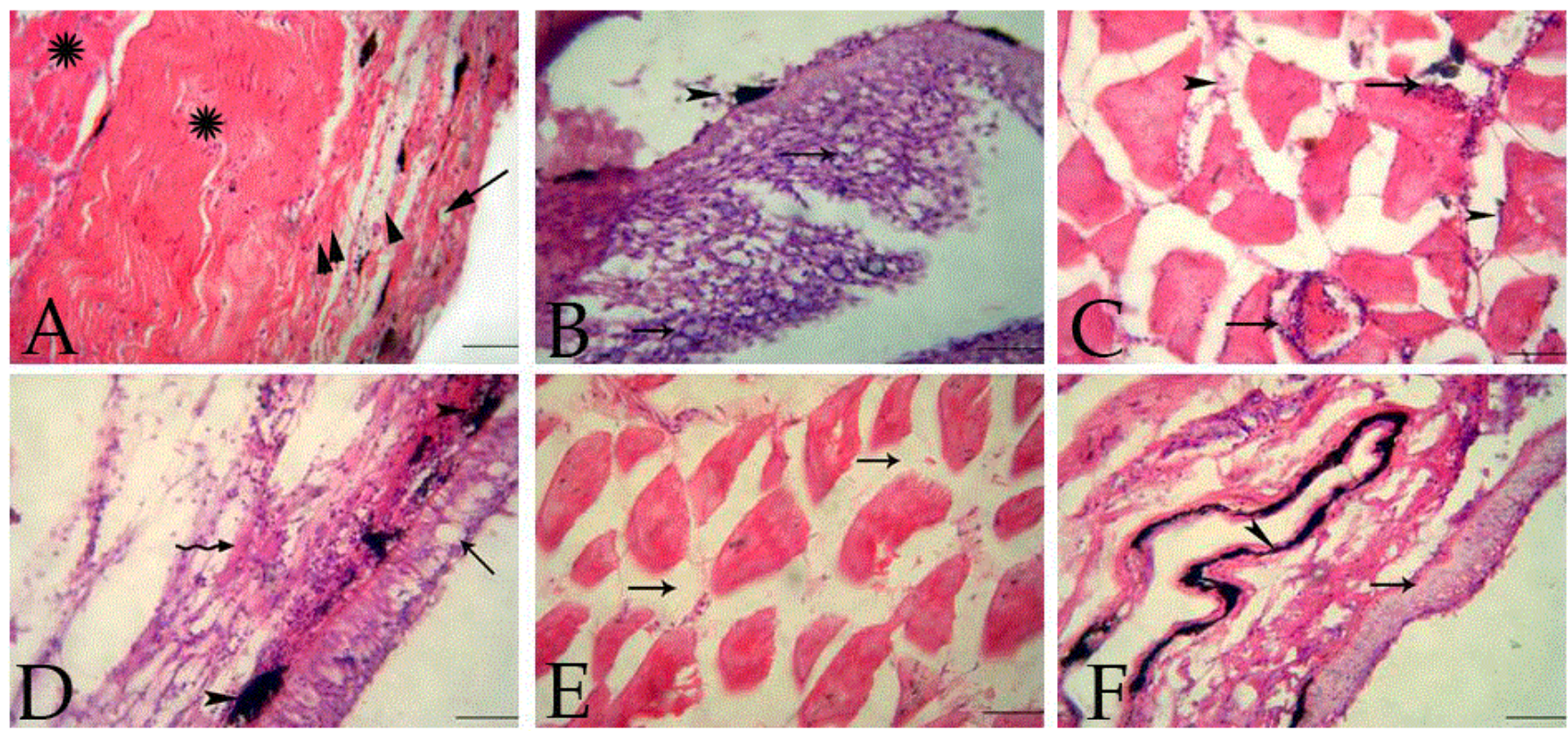

Figure 4A: Section of O.niloticus skin of control group showing normal epidermis (arrow), dermis (arrow head) and dermal skeletal muscles (star), H\&E (Bar=100 $\mu \mathrm{m}$ ). Figure 4B: Section of O.niloticus skin of second group showing intact epidermis with severe proliferation of epidermal cells, spongiosis and hydropic degeneration (arrows) besides few melanin carrying cells (arrowhead),H\&E (Bar=100 $\mu \mathrm{m})$. Figure 4C: Section of O.niloticus skin of second group showing Zenker's necrosis infiltrated with numerous round cells (arrows) and edema (arrowheads), H\&E (Bar=100 $\mu \mathrm{m}$ ). Figure 4D: Section of O.niloticus skin of third group showing increased of mucous cells (arrow) and slight vacuolations of the epidermal cells. Edema and aggregations of the leukocytes (irregular arrow) and melanin-carrying cells (arrowhead) were seen in the dermis, H\&E (Bar=100 $\mu \mathrm{m})$. Figure 4E: Section of O.niloticus skin of third group showing edema and focal hyaline degeneration in the skeletal muscles (arrows), H\&E (Bar=100 $\mu \mathrm{m}$ ). Figure 4F: Section of O.niloticus skin of fourth group showing intact epidermis (arrow) with activation of melanomacrophages in the dermis (arrowhead), H\&E (Bar=100 $\mu \mathrm{m})$.

\section{References}

1. Geist J (2011) Integrative fresh water ecology and biodiversity conservation. Ecol Indic 11: 1507-16.

2. Schäfer RB, von der Ohe PC, Kühne R, Schuüuürmann G, Liess M (2011) Occurrence and toxicity of 331 organic pollutants in large rivers of north Germany over a decade (1994 to 2004). Environ Sci Technol 45: 6167-6174.

3. Barbieri E (2009) Effect of 2,4-D herbicide (2,4-dichlorophenoxyacetic acid) on oxygen consumption and ammonium excretion of juveniles of Geophagus brasiliensis (Quoy \& Gaimard, 1824) (Osteichthyes, Cichlidae). Ecotoxicology 18: 55-60.

4. Kalavathy K, Sivakumar AA, Chandran R (2001) Toxic effect of the pesticide Dimethoate on the fish Sarotherodon mossambicus. Journal of Ecological Research and bioconservation 2: 27-32.

5. Srivastav AK, Srivastava SK, Mishra D, Srivastav SK (2002) Ultimobranchial Gland of Freshwater Catfish, Heteropneustes fossilis in response to Deltamethrin Treatment. Bulletin Environmental Contamination Toxicology 68: 584-591.

6. US EPA (2002b) Interim Reregistration Eligibility Decision for Chlorpyrifos Prevention, Pesticides and Toxic Substances, Washington, DC EPA 738-R-01-007.

7. Chiovarou ED, Siewicki TC (2008) Comparison of storm intensity and application timing on modeled transport and fate of six contaminants. Sci Total Environ 389: 87-100.

8. Mulrooney JE, Wolfenbarger DA, Howard KD, Goli D (1998) Efficacy of ultra low volume and high volume applications of fipronil against the boll weevil. Journal of Cotton Science 2:110-116.

9. Jennings KA, Canerdy TD, Keller RJ, Atieh BH, Doss RB, et al. (2002) Human exposure to fipronil from dogs treated with frontline. Vet Hum Toxicol 44: 301-303.
10. US EPA (1996) New Pesticide Fact Sheet-Fipronil; EPA 737-F-96-005; US Environmental Protection Agency, Office of Prevention, Pesticides and Toxic Substances, Office of Pesticide Programs, US Government Printing Office Washington, DC 1-10.

11. Tomlin CDS (2006) The Pesticide Manual, A World Compendium (14th edn). British Crop Protection Council: Hampshire, England pp: 462-464.

12. Jackson D, Cornell CB, Luukinen B, Buhl K, Stone D (2009) Fipronil Technical Fact Sheet; National Pesticide Information Center, Oregon State University Extension Services.

13. Tingle CC, Rother JA, Dewhurst CF, Lauer S, King WJ (2003) Fipronil: environmental fate, ecotoxicology, and human health concerns. Rev Environ Contam Toxicol 176: 1-66.

14. Environmental Protection Agency (US EPA) (2011) Fipronil Summary Document Registration Review: Initial Docket June 2011 Washington, DC EPA-HQ-OPP-2011-0448.

15. Noga EJ (1996) Fish diseases: Diagnosis and treatment Mosby-year book. Inc St Louis, Missouri p.367.

16. Schultz A (1987) Methods in clinical chemistry. The CV Mosby Co St Louis PP: 742-746.

17. Rajaraman V, Nonnecke BJ, Franklin ST, Hammell DC, Horst RL (1998) Effect of vitamins $\mathrm{A}$ and $\mathrm{E}$ on nitric oxide production by blood mononuclear leukocytes from neonatal calves fed milk replacer. J Dairy Sci 81: 3278-3285.

18. Reitman S, Frankel S (1957) A colorimetric method for the determination of serum glutamic oxalacetic and glutamic pyruvic transaminases. Am J Clin Pathol 28: 56-63.

19. Foster LB, Dunn RT (1974) Single-antibody technique for radioimmunoassay of cortisol in unextracted serum or plasma. Clin Chem 20: 365-368

20. Patton CJ, Crouch SR (1977) Enzymatic determination of urea. Anal Chem 49: 466-469. 
Citation: El-Murr AE, Imam TS, Hakim Y, Ghonimi WAM (2015) Histopathological, Immunological, Hematological and Biochemical Effects of Fipronil on Nile Tilapia (Oreochromis Niloticus) . J Veterinar Sci Technol 6: 252. doi:10.4172/2157-7579.1000252

Page 9 of 9

21. Henry TJ (1974) Determination of serum creatinine. Clin Chem Principles and Techniques, (2nd Edn) Harper and Row publisher, NewYork.

22. Natt M, Herric K (1952) A new diluent for counting the red and white cells of chickens. Poult Sci 31: 335.

23. Jain N (1986) Schalm's Veterinary Heamatology. (4th Edn) Lea and Fibiger, Philadelphia, USA pp: 66-67.

24. Larsen H (1964) Comparison of various methods of haemoglobin determination of catfish blood. Progressive fish Culturist 26: 11-15.

25. Bancroft JD, Gamble M (2008) Theory and Practice of Histological Techniques. (5th edn) Churchill Livingstone. New York, London, Philadelphia pp: 281-285.

26. SAS (Statistical Analysis System) Institute, Inc (1996) The statistical analysis system for windows. Cary (Ed) N C. USA, 6: 12.

27. Kidd H, James D (1991) The Agrochemicals Handbook, (3rd Edn) Royal Society of Chemistry Information Services, Cambridge, UK.

28. Colliot F, Kukorowski KA, Hawkins DW, Roberts DA (1992) Fipronil: new soil and foliar broad spectrum insecticide. Brighton Crop Protection Conference-Pests and Diseases 2: 29-34.

29. Gupta SK, Pal AK, Sahu NP, Saharan N, Akhtar MS, et al. (2013) Haemato-biochemical Responses in Cyprinuscarpio (Linnaeus, 1758) Fry Exposed to Sub-lethal Concentration of a Phenylpyrazole Insecticide. Fipronil Proc Natl Acad Sci, India. Sect B Biol Sci.

30. Clasen B, Loro VL, Cattaneo R, Moraes B, Lópes T, et al. (2012) Effects of the commercial formulation containing fipronil on the non-target organism Cyprinus carpio: implications for rice-fish cultivation. Ecotoxicol Environ Saf 77: 45-51.

31. Van der Oost R, Beyer J, Vermeulen NP (2003) Fish bioaccumulation and biomarkers in environmental risk assessment: a review. Environ Toxicol Pharmacol 13: 57-149.

32. Rao JV (2006c) Toxic effects of novel organophosphorous insecticide (RPR-V) on certain biochemical parameters of euryhaline fish, Oreochromis mossambicus. Pestic. Biochem Physiol 86: 79-84.
33. Morowati M (1997) Inhalation toxicity studies of thimet (phorate) in male Swiss albino mouse, Mus musculus: I. Hepatotoxicity. Environ Pollut 96: 283-288.

34. De Aguiar LH, Moraes G, Avilez IM, Altran AE, Corrêa CF (2004) Metabolical effects of Folidol 600 on the neotropical freshwater fish matrinxã, Brycon cephalus. Environ Res 95: 224-230.

35. Arshad N, Shabbir G, Aleem S, Arshad M (2007) GOT is one of the enzymes, which gives valuable diagnostic information for a number of disease conditions. Asian J Exp Sci 21: 239-24.

36. Gupta SK, Pal AK, Sahu NP, Saharan N, Mandal SC, et al. (2012) Dietary microbial levan ameliorates stress and augments immunity in Cyprinuscarpio fry (Linnaeus, 1758) exposed to sublethal toxicity of Fipronil. Aquaculture Research pp: 1-14.

37. Ghisi Nde C, Ramsdorf WA, Ferraro MV, de Almeida MI, Ribeiro CA, et al. (2011) Evaluation of genotoxicity in Rhamdia quelen (Pisces, Siluriformes) after sub-chronic contamination with Fipronil. Environ Monit Assess 180: 589-599.

38. Gill KK, Dumka VK (2013) Haematological alterations induced by subchronic oral exposure of buffalo calves to fipronil and fluoride. Research report Fluoride 46: 65-72.

39. Melo GC (2004) Sublethal effects of organophosphate folido 1600 action in the liver of the fish freshwater catfish quelen (Quoy \& Gaimard, 1824): An anal-216 New Advances and Contributions to Fish Biologyise histopathology. Thesis. UFPR, Curitiba, Pr, 2004. Dissertation (Master in Cell and Molecular Biology) -Graduate Program in Cellular and Molecular Biology, Division of Biological Sciences, Federal University of Paraná, Curitiba.

40. Ojha J (1999) Fish gills: Potential indicators of ecodegradation of aquatic environments. In Mittal AK, Eddy FB, Dattamunshi JS (Eds), Water/air transition in biology, New York 18: 263-279. 